This manuscript has been accepted for publication in Journal of Service Management. Please do not distribute or cite it without first contacting the authors.

\title{
Articulating the Service Concept in Professional Service Firms
}

\author{
Ahmad Beltagui* \\ University of Wolverhampton Business School, \\ Nursery Street, Wolverhampton, WV1 1AD, U.K. \\ a.beltagui@wlv.ac.uk \\ Kjartan Sigurdsson and Marina Candi \\ Reykjavik University Center for Research on Innovation and Entrepreneurship \\ Menntavegur 1, 101, Reykjavik, Iceland \\ kjartans08@ru.is, marina@ ru.is \\ Johann CKH Riedel \\ Nottingham University Business School, University of Nottingham \\ Jubilee Campus, Wollaton Road, Nottingham, NG8 1BB, U.K. \\ johann.riedel@nottingham.ac.uk
}

*corresponding author

\section{Acknowledgement}

Part of the funding for this work has been provided from the European Union's Seventh Framework Programme for research, technological development and demonstration under grant agreements no.

251383 and 324448 


\begin{abstract}
Purpose: This study proposes a solution to the challenges of Professional Service Firms (PSF), which are referred to as cat herding, opaque quality and lack of process standardization. These result from misalignment in the mental pictures that managers, employees and customers have of the service. The study demonstrates how the process of articulating a shared service concept reduces these challenges.

Methodology: A narrative methodology is used to analyze the perspectives of old management, new management and employees during organizational change in a PSF-a website design company growing to offer full-service branding. Group narratives are constructed using longitudinal data gathered through interviews and fieldwork, in order to compare the misaligned mental pictures and show the benefits of articulating the service concept.
\end{abstract}

Findings: Professional employees view growth and change as threats to their culture and practice, particularly when new management seeks to standardize processes. These threats are revealed to stem from misinterpretations caused by miscommunication of intentions and lack of participation in decision making. Articulating a shared service concept helps to align understanding and return the firm to equilibrium.

Research Limitations: The narrative methodology helps unpack conflicting perspectives, but is open to claims of subjectivity and misrepresentation. To ensure fairness and trustworthiness, informants were invited to review and approve the narratives.

Originality: The study contributes propositions related to the value of articulating a shared service concept as a means of minimizing the challenges of PSFs.

Keywords: Professional Service Firms, Service Concept, Narrative, Cat Herding 


\section{Introduction}

The company was in the middle of an exciting transition. They were expanding their services from web development to also encompass print media, branding and just about anything their customers could need. The workforce had grown, almost overnight, from twelve to nearly forty. Everyone had been working hard for the last few months in cramped conditions before the company moved to a larger office. The new Managing Director could see everyone had been under a lot of stress. He wanted to make a grand gesture to help bring everyone together and to welcome the new recruits. It seemed like that was how things were done before, when the original Founder of the company was in charge. Everyone worked hard, but they all had fun. So the Managing Director decided to throw a birthday celebration in the office for one of the new people he had hired. There was food and champagne. Surely everyone would appreciate the gesture. Or so he thought. For the people who had been at the company almost from the start, this seemed to reinforce everything they thought. Things had changed. Before, everything was about people. They were respected as experienced professionals. Now they would be just cogs in the machine. Everything seemed to be about management and process. To add insult to injury, just the week before when one of the original employees had their $40^{\text {th }}$ birthday all they got was a card and a small gift.

This paper examines the case of a Professional Service Firm (PSF) referred to as ServCo. It focuses on a period of turbulent organizational change precipitated by a merger between ServCo and another company, whose owner was then appointed as ServCo's Managing Director (MD) to oversee an expansion in ServCo's services and client base. As illustrated by the vignette above, these changes were perceived differently by management and employees. This work attempts to diagnose the challenges by examining events using a narrative method that unpacks the events from three perspectives: those of the Founder (old management), MD (new management) and employees. During the changes, employees were involved in an exercise to define ServCo's responsibilities to employees, customers and the environment, resulting in the articulated service concept: "great services, delivered ethically", . The findings of this research lead to the proposition that developing a shared and articulated service concept (Goldstein et. al., 2002) helps to overcome some of the challenges identified in the literature on PSFs (von Nordenflycht, 2010).

Professional services have long been recognized as a distinct category of service. They are characterized by high labor content, high customization and high customer contact (Schmenner, 1986; Wemmerlöv, 1990). An additional characteristic is the presence of a professionalized workforce, i.e. employees whose knowledge, ethical codes and loyalties may be tied to professional bodies outside of the firm. This means the knowledge base and key resources of a PSF may lie outside the scope of

\footnotetext{
${ }^{1}$ The wording is modified from the actual in the interest of maintaining ServCo's anonymity.
} 
managerial control. These characteristics combine to form three related challenges for managers in PSFs, referred to as cat herding, opaque quality and lack of process standardization (Maister, 1993; Løwnedahl, 2005; Von Nordenflycht, 2010). Professional employees are knowledge workers, who value autonomy and cannot be easily controlled; their knowledge usually exceeds that of customers and managers, making the quality of their work difficult to see and measure. The high level of variation in services makes standardization and control of processes difficult. As the importance of knowledge workers and the prevalence of knowledge based services increases, these challenges are becoming pertinent to managers in a broader range of service firms. In today's information driven economy, service management increasingly involves harnessing the brains, not backs, of what Kelley (1985) refers to as gold-collar workers.

PSFs' challenges are exacerbated by organizational changes, which create additional friction between managers and professionals. Professionals demand participation in every aspect of decision making and do not appreciate interference. Unfortunately managers often take the wrong approach when they under-specify the strategic ends for a PSF and over-specify the operational means (Raelin, 1986). As firms grow in size, maintaining performance usually requires management systems to control resources, measure quality and standardize processes (Simons, 2000). Such changes typically generate tensions in organizations, because they are viewed by professionals as a threat to their legitimacy (Brown, 1998; Landau et. al. 2014). Understanding the consequences of organizational changes in PSFs requires an understanding of the social groups within the organization and how the events are viewed as part of competing narratives. These narratives represent the different interpretations that managers and professionals give to a sequence of events and can help to explain the reasons for tensions in the organization.

Services in general and professional services in particular are processes, or journeys, which are experienced differently by different people. In the absence of physical and objective form, individuals form a mental picture of the service (Clark et al., 2000). The challenges of PSFs can be seen to arise when the mental pictures of managers, employees and customers diverge. The cat herding challenge stems from a misalignment that occurs when managers' mental picture of their role is that of controlling resources, but employees see themselves as autonomous. Løwendahl (2005) compares the challenge to playing chess with pieces that move themselves. Opaque quality results from misalignment of knowledge between employees and customers, which arises from differing mental pictures of the service. Lack of process standardization is, by definition, a challenge only if managers perceive the nature of the service as one that can be standardized, rather than entirely customized. This paper explores how aligning the mental pictures of managers, employees and customers can help overcome these challenges. In other words, creating a shared and articulated service concept (Goldstein et al., 2002). 
This work makes a number of important contributions. First, it contributes to the sparse literature on the service concept by conceptualizing the challenges of PSFs as misalignments in mental pictures of the service. Second, it contributes to knowledge on PSFs by examining these misaligned mental pictures through a narrative methodology. Finally, it offers implications for managers of PSFs by demonstrating how a shared and articulated service concept can help overcome the challenges of PSFs.

In the next section, the literature on PSFs and the service concept are reviewed to generate a research model. Next the ethnographic data collection and narrative analysis methods used are explained. Data were collected using interviews at different stages and through a period of participant observation fieldwork by one of the research team members The rich, qualitative data are presented in the form of three narratives, written in first person to explain the perspectives of old management, new management and employees. The discussion focuses on the salient issues of the case, drawing parallels with existing literature and demonstrating the value of the service concept in overcoming some of the challenges. Finally, a set of propositions is derived from the findings, from which directions for further research are developed.

\section{Background}

Professional services encompass activities as diverse as accounting, law, engineering consultancy, medicine, sports, and social work (von Nordenflycht, 2010). The distinguishing feature of these services is their knowledge-intensive nature (Løwendahl et al., 2001) and dependence upon expert talent (Teece, 2003). In most organizations, managers' strategic responsibilities concern controlling resources in search of competitive advantage. In PSFs, however, the key resource is knowledge, which is largely controlled by the employees (Løwendahl et al., 2001). The knowledge is often tacit or may be drawn from sources outside of the organization. The experts themselves are often cosmopolitan (Raelin, 1986) in their career outlook, meaning that "carrot-and-stick" motivation typically fails (Kelley, 1985, p14). Threats of unemployment are ineffective since experts can rely on their talent to find new employment and extrinsic rewards are often secondary to the informality, autonomy and respect that they demand (Goodale et al., 2008).

Unlike other firms, PSFs allow their resources to leave in the elevator every night and hope they return in the morning (Løwendahl, 2005). As a result, contractual lock-in is weak, but having great colleagues (Teece, 2003) or the freedom to choose how they work (Starbuck, 1992) motivates professionals. Employees in PSFs are pivotal in building and maintaining relationships with customers (Sieg et al., 2012). Their importance puts them in a position to expect autonomy and informality in their working environment (von Nordenflycht, 2010). For managers, the result is referred to metaphorically as the cat herding challenge (ibid.). 
The quality of any service can be difficult to assess prior to experiencing it (Harvey, 1998) but PSFs have an additional agency problem caused by a lack of understanding of service development and delivery processes (Goodale et al., 2008). Unlike mass produced services such as fast food or dry cleaning, professional service customers usually have less understanding of their desired outcomes and simply emphasizing excellence in customer service may not be sufficient (Sweeney et al., 2011). Customers may assess what they cannot see or understand by evaluating what they can, meaning that they look for clues in the experience to judge the quality of a professional service (Berry et al., 2004). These can come from the way employees dress and behave, or the design of buildings and interiors. Customers and managers are therefore faced with the challenge of opaque quality.

Finally, professionals value the stimulation of solving problems, facing new challenges and working collaboratively with like-minded colleagues. This inverts the logic of traditional hierarchies, which follow Max Weber's idea that workers should apply standard operating procedures, while managers deal with exceptions that demand problem solving. In PSFs, standard operating procedures may not be effective (Kellogg and Nie, 1995) and challenging problems are solved by workers (professionals) not managers. This leads to the third challenge, a lack of process standardization.

\section{Evolution of PSFS}

PSFs vary, but the literature suggests that they follow a similar progression in their evolution and managerial responses to success. Løwendahl (2005) describes three approaches to strategic focus and resource control, which can be viewed as distinct forms of PSF, or a typical pattern of evolution, as shown in Figure 1. PSFs move from stage A, with a strategic focus on building client relations and control of resources is left to individual professionals, to stage B, with a focus on adapting ready solutions and controlling resources centrally. They may then settle on stage $\mathrm{C}$, where there is more recognition of creative problem solving and more autonomous control of resources by teams of professionals. 


\begin{tabular}{|l|c|c|c|}
\hline \multicolumn{1}{|c|}{$\begin{array}{c}\text { Strategic } \\
\text { Resource } \\
\text { Base }\end{array}$} & Client Relations & $\begin{array}{c}\text { Creative Problem } \\
\text { Solving }\end{array}$ & $\begin{array}{c}\text { Adaptation of Ready } \\
\text { Solutions }\end{array}$ \\
\hline $\begin{array}{l}\text { Organization } \\
\text { Controlled } \\
\text { Resources }\end{array}$ & & $\begin{array}{c}\text { Stage B } \\
\text { Managers seek more } \\
\text { control over resources } \\
\text { and efficiency of output }\end{array}$ \\
\hline $\begin{array}{l}\text { Team-Based } \\
\text { Individual and } \\
\text { Collective }\end{array}$ & $\begin{array}{c}\text { Stage C } \\
\text { A balance is achieved } \\
\text { between } \\
\text { efficiency/creativity and } \\
\text { control/autonomy }\end{array}$ & \\
\hline $\begin{array}{l}\text { Individually } \\
\text { Controlled } \\
\text { Resources }\end{array}$ & $\begin{array}{c}\text { PSF controlled informally } \\
\text { by professionals, } \\
\text { emphasis on building } \\
\text { relationships }\end{array}$ & & \\
\hline
\end{tabular}

Figure 1 - Stages in the evolution of PSFs (adapted from Løwendahl, 2005)

Most PSFs start small, usually set up by an individual professional or a small group, who typically share similar characteristics, interests and educational backgrounds. In such circumstances, there is little need for strategy or systems for control (Simons, 2000). Knowledge resides in individuals, who are usually incentivized financially (for example in partnerships, such as law firms) or socially through their connections with the group. The focus of a small PSF is typically on building client relations in order to secure ongoing projects (Stage A in Figure 1). As the firm grows, however, a number of changes take place. Firstly, co-ordination becomes more difficult so costs rise and greater process control begins to seem necessary (Lewis and Brown, 2012). Secondly, the dynamic relationship between the resource base and choice of clients becomes clear, making strategic planning seem necessary (Løwendahl et al., 2001). The resources determine which clients' projects can be delivered, while the projects delivered determine the development of resources. Each project adds to the individual knowledge of the professionals who work on it and potentially adds to the collective knowledge of the firm (Nonaka and Takeuchi, 1995). The firm therefore seeks more complex or diverse projects to capitalize on and grow its knowledge base, while simultaneously seeking to codify this knowledge into routines that allow efficiency (Gilbert, 2005). This means PSFs often seek to place control of resources in the organization and move the strategic focus towards adaptation of ready solutions (Løwendahl, 2005). The change is from what Friedman (1977) refers to as responsible autonomy towards technical control, using Taylorist methods. Professionals accustomed to holding a position of strength are unlikely to welcome this change, even if they appreciate the reasons. Additionally, growth may require an increase in the workforce, which again alters the social dynamics 
in the firm. Stage B in Figure 1 represents a managerial view of the firm that may be misaligned with that of the professionals. A compromise between the two extremes in Stage $\mathrm{C}$ allows for knowledge to be shared by teams of individuals and, while seeking efficiency, allows for creativity of these individuals, rather than turning professional services into standard products (Jaakkola, 2011).

Maister (1993) categorizes PSFs as expertise-based, which is comparable to Stage A, and routinebased, which matches Stage B. Additionally, he discusses grey-hair based PSFs that invite customers to "hire us because we have been through this before; we have practice at solving this type of problem" (p5). Like Løwendahl's (2005) Stage C, this allows a balance between the extremes of expertise-based and routine-based, leaving room for individual creativity, but seeking to better manage the knowledge of the firm through teams or some level of process.

\section{The Service Concept}

The term service concept was originally used by Sasser et al., (1978) to describe the bundle of implicit/explicit services and facilitating goods that are provided to customers. These elements are also commonly referred to as the service package (Roth and Menor, 2003). They help firms to understand the core content of their offerings as well as the operations and processes required to deliver them and the customer's experience of the outcome (Hakanen and Jaakola, 2012). Customers view a service as an experience, rather than a collection of components. The exception is when service failure makes the components and their poor connections evident (Goldstein et al., 2002). Clark et al. (2002) describe the service in the minds of customers and those who develop and deliver services. They describe a service concept as a mental picture that describes the experience offered by a service. From this perspective, service failure can be explained as a lack of alignment between strategic intent and customer expectations. For the purposes of this research, the service concept is seen as a missing link between the perspectives of management, employees and customers (Goldstein et al., 2002). This is illustrated in Figure 2, in which the three challenges of PSFs are presented as misalignment between the mental pictures of management, employees and customers respectively. 


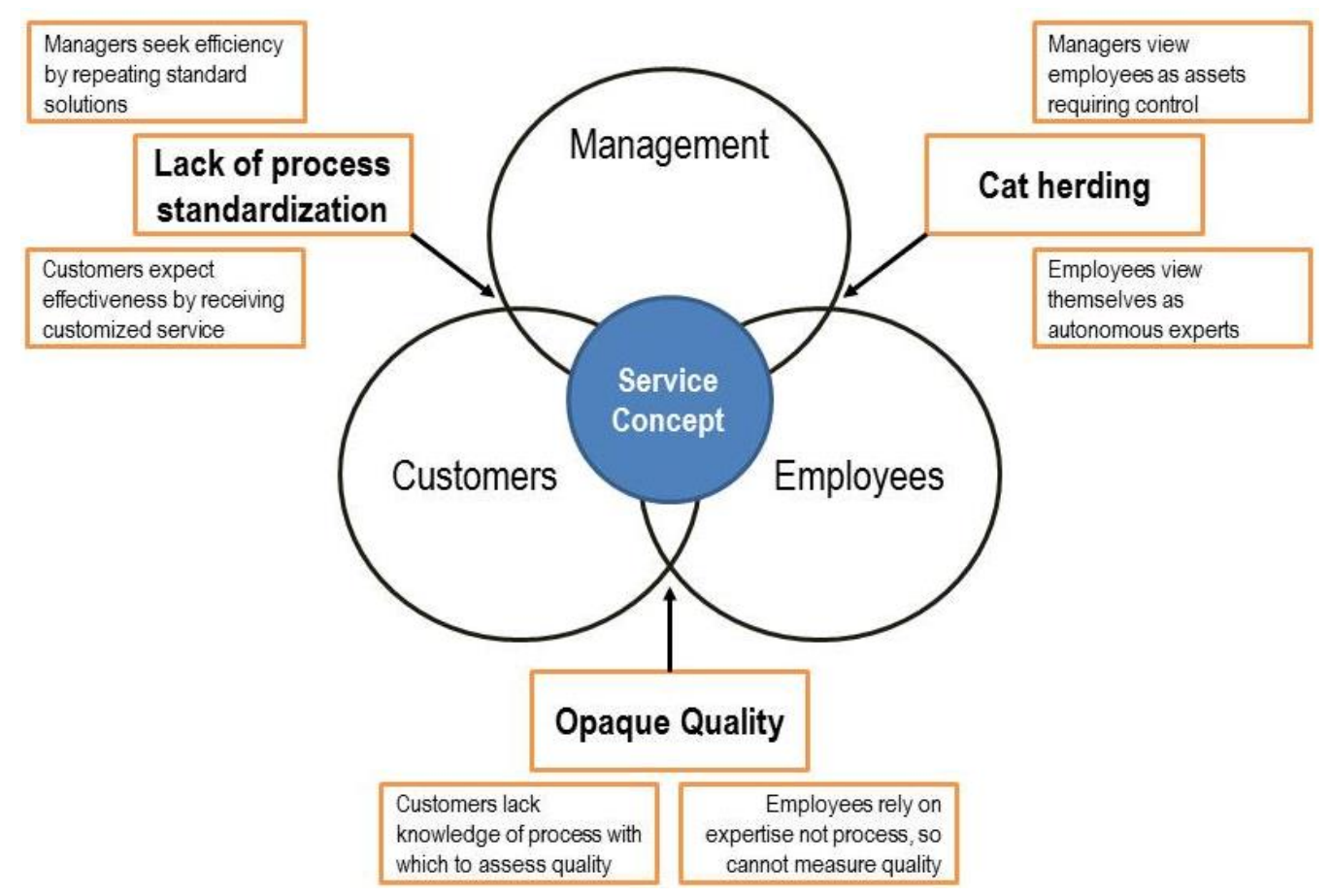

Figure 2 - The three challenges of PSFs (von Nordenflycht, 2010) result from misalignment in mental pictures (based on Goldstein et al., 2002).

Parallels can be drawn with product development, in which misaligned mental models explain poor usability (Norman, 1990). For example regulating the temperature of a refrigerator requires the user to understand the designer's mental model to know whether increasing the number means warmer (higher temperature) or colder (higher power output).

Based on prior literature (Goldstein et al., 2002; Johnston et al., 2011) the service concept is defined as a shared and articulated understanding of the nature of the service, its delivery and consumption.

A simple offering can be described by its function (a kettle boils water, a bank account stores money) but more complex offerings need to be experienced to be understood (Levitt, 1981; Harvey, 1998). In professional services, information asymmetry means that customers and managers have little understanding of what employees do (Løwendahl, 2005). Furthermore, managers are restricted in their level of control over employees, so are expected to specify the ends, but allow employees to specify the means to achieve them (Raelin, 1986). Therefore in PSFs, the employees may have an important role in developing, agreeing and upholding the service concept.

\section{Research Design}

To explore the misalignments in mental pictures that drive the three challenges of PSFs and demonstrate how a shared and articulated service concept may help overcome them, a narrative method is used to explore the case of a PSF (ServCo)-which initially started as a website and software development firm and transitioned to a full-service marketing agency. Specifically, in von 
Nordenflycht's (2010) taxonomy, ServCo can be viewed as a technology developer, meaning that it faces all three challenges of cat herding, opaque quality and lack of process standardization, which are typically overcome through means such as alternative compensation, autonomy and informality.

Figure 3 shows a timeline of key events in the company's history. The research relationship commenced before the changes that the present research focuses on, through previous research on design and customer experience. During this time, two key events occurred. Firstly, the merger of ServCo with another company, leading to the founder stepping down and appointing his new business partner as MD. Secondly, the definition of a service concept for the newly merged firm, conducted by a group of employees to capture ServCo's responsibilities to its customers, employees and the environment. The exercise resulted in a policy document listing responsibilities to customers that explain the concept of "great services, delivered ethically". In particular, however, the policy outlines the employees' demands for autonomy and informality in their workplace, which represents what they see as ethical.

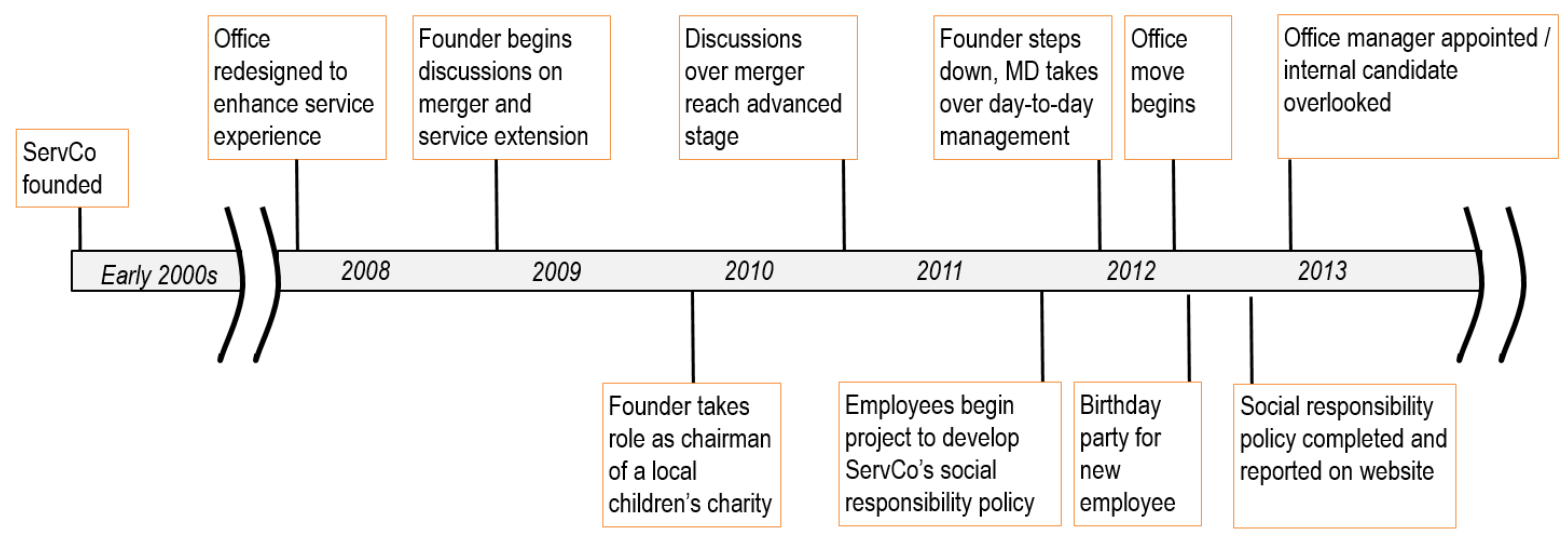

Figure 3 - Timeline showing key events for ServCo.

\section{Narrative Methods}

A single case study can offer depth of understanding, rather than scratching the surface of multiple cases (Dubois and Gadde, 2014). Although researchers often follow Eisenhardt's (1989) argument that multiple cases lead to better theory, Dyer and Wilkins' (1991) response is that single cases offer better stories. Stories add value because they do not merely present facts about events, but seek to infuse the facts with meaning-"paradoxically the inaccuracy, the distortion or even the lie in a story can offer a path towards the deeper truth it contains" (Gabriel, 2000, 135). All events and actions can have symbolic interpretations-for example the difference between a twitch and a wink (Geertz, 1973). The approach used focuses on how these events are interpreted within each of the informants' narratives, giving different understandings of historical events. The main criteria for convincing readers with narratives are authenticity, plausibility and criticality (Golden-Biddle and Locke, 1993). 
This is achieved through thick descriptions that demonstrate understanding of every day events in the lives of the informants, by relating the events to theoretical concepts from literature and by comparing alternative viewpoints to allow critical reflections.

Narratives are descriptions that provide stories of related events (Abbott, 1992). Their value in research comes from their acknowledgement of the identity of actors, the voice of the story-teller and the moral context (Pentland, 1999). The addition of these elements helps to clarify the particular perspective from which a sequence of events is understood. This in turn enables complex processes to be viewed from multiple perspectives and to improve the capacity for process theory development (Pentland, 1999). Narratives help researchers understand a sequence of events, how and why phenomena emerge, develop, grow or terminate over time (Langley et al., 2013). Additionally, they allow analysis of the multiple competing, or conflicting, perspectives that co-exist in organizations and help to explain the underlying reasons they differ (Landau et al, 2014).

To understand the conflicting mental pictures within ServCo, the timeline of critical events shown in figure 3 was constructed and divided into the broad periods of before, during and after the change. The case data were analyzed by constructing group narratives (Brown, 1998; Narayanan et al., 2009; Landau et al., 2014). Interview and field data were used to describe the same events using three group narratives. The first narrative tells the story from the founder's perspective, the second from the new MD's and the third from the perspective of ServCo employees.

Although written in the first person, the three narratives were constructed by the research team, not the informants themselves. To ensure fairness and trustworthiness (Guba and Lincoln, 2005), preliminary versions were shared with informants so they could comment, add detail and correct any misinterpretations. These groups often compete for legitimacy and power, particularly in PSFs, where managers and employees have differing perspectives. Therefore an in-depth understanding of the behaviors and interactions within and between the groups is vital to understand the dynamics of the case.

\section{Case and Data Collection}

An ethnographic approach was used "to understand how culture is constructed and negotiated, particularly as a result of interactions between groups" (Chambers, 2003, p391). An overview of the methods employed is shown in figure 4. In a process of systematic combining (Dubois and Gadde, 2002), the research design, data collection and theoretical explanations evolved in parallel as the study progressed. Semi-structured interviews with managers were recorded and transcribed throughout each of the three phases of the study-before, during and after the reported changes. Access was gained to management meetings and informal conversations with the founder took place at conferences and other occasions outside of the workplace. 
A total of 36 interviews were recorded and transcribed. Such interviews provide a valuable source of analyzable data, but often actions and symbolic interaction reveal more than words. Organizations consist of groups of people who form communities and subcultures, reflected in their social interactions, behaviors and even the way they dress (Rosen, 1985). For this reason, the most important source of data about employees and their mental pictures was a 13-month continuous period of participant observation spanning phases two and three. During this time, one member of the research team was based in the company and had daily contact with employees as well as participating in social events outside of the workplace. Semi structured interviews were used to capture employees' views of the service concept, development of the social responsibility policy and relationships with the new management. Field notes and personal memos during the field work were also used to understand their perspectives and construct the narratives.

Ethnographic research requires a high degree of contact between researchers and participants. Researchers risk becoming too close to the participants and losing sight of the academic and practitioner communities they intend to inform through their research. To guard against this risk of going native, all the researchers were generally present at different times so that all gained a unique viewpoint and together could reach a balanced perspective. During the ethnographic portion of the study, when one of the research team members was present full time, another member was based in another country and had no direct contact with the company. Thus the inside and outside perspectives could be balanced during analysis.

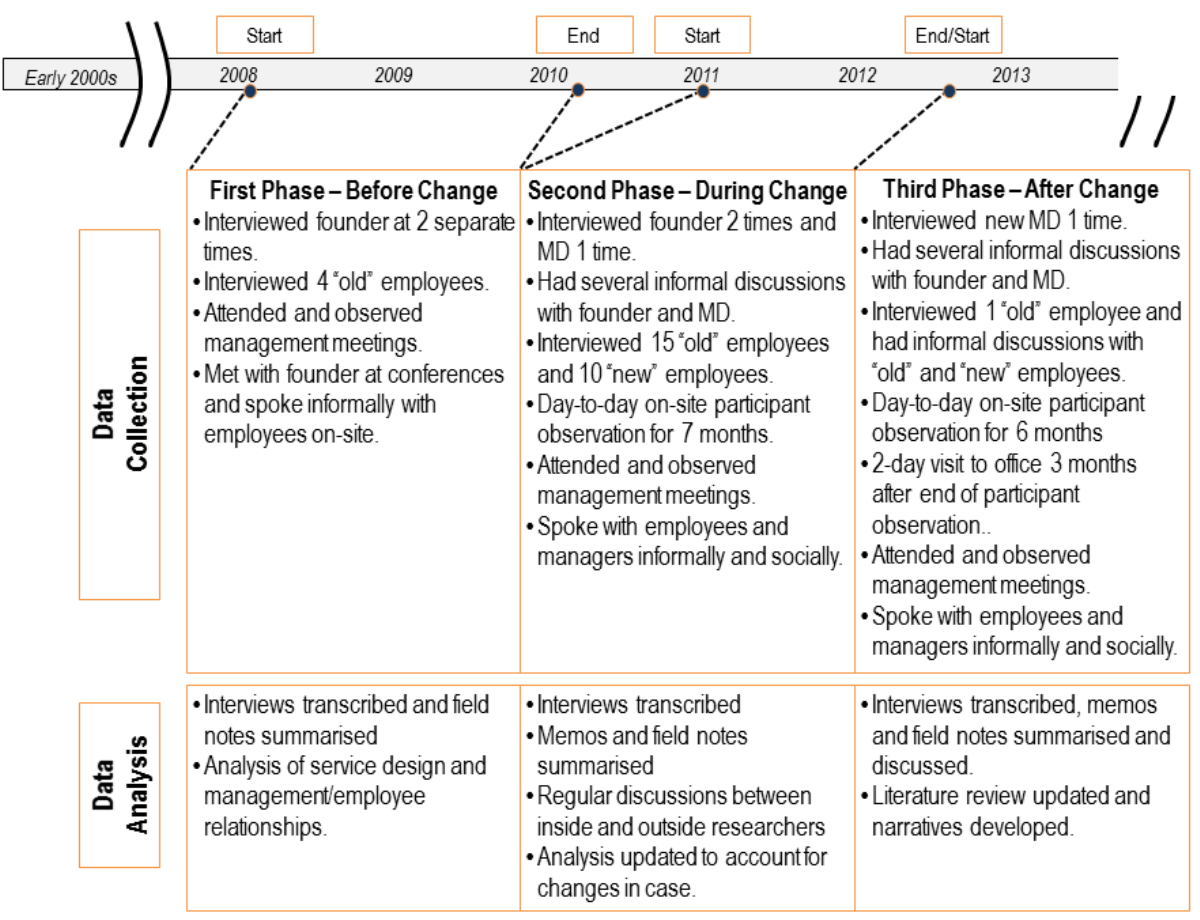

Figure 4 - Timeline showing data collection and analysis before, during and after change in ServCo 
Narrative case studies help to understand employees' reactions to managerial decisions. For example, Brown's (1998) study of resistance to the introduction of information systems in a hospital used group narratives to reveal the project as a threat to professional workers. While all of the groups shared the intention of improving patient care, poor communication of the project's goals led to adversarial tensions between developers and users. By analyzing the group narratives of those affected, the threat was diagnosed and could be resolved. The intent of the present study is to diagnose the managerial challenges in the case of ServCo and to provide recommendations for other PSFs experiencing growth.

\section{Findings}

The periods before, during and after the changes in management, size and scope of ServCo are examined from three different perspectives: those of the old management (the Founder), new management (Managing Director) and employees. These perspectives are presented as narratives in the first person. Other than the direct quotations included, however, these narratives are not the words of the people observed. They were constructed by the research team for the purposes of analysis and presentation.

\section{Old Management (Founder's) Narrative}

\section{Before the change}

I started ServCo because I saw an opportunity to offer a service as the internet was becoming more popular and potential customers knew they needed a website but didn't know how to go about building one. I made use of my contacts (in the music industry) and I set up a company that treats customers and employees the way I think they should be treated. I believe ServCo can only be successful if employees and customers feel comfortable and happy. Most new customers come to us through word of mouth, because they know they need something but don't know what it is or have much technical understanding. The important thing was to build trust with customers so they refer people who trust them to ServCo. We offered a very personalized service, with a lot of contact between customers and our employees. New customers need to be convinced that ServCo is both technically very capable and can sustain a long-term relationship. We made sure they that impression by designing everything that customers see and touch.

In the past we always visited our customers to negotiate a project and get the sale. That was convenient for customers, but I didn't feel we could control the customer's experience or really get them to trust us. The problem was the office we worked in wasn't one I was proud of or keen to show to customers. So after we had been there a few years and a new office space became available we 
moved. We spent a lot of money and put a lot of work into completely renovating and redesigning the new office, where we planned every detail to communicate something to customers, from the paper they touch to the fonts we use, to the cars sitting outside. It's all there to send a message. In the meeting room, we didn't want to have any boring desks and chairs; we wanted customers to feel comfortable. So we have a coffee table and I had the sofas made "by the same lady who made my sofa at home" (Founder). The paintings on the wall have colors and images based on the company's branding. Once the office was designed the way I wanted it, we started to make every effort to bring our customers here. We would pick them up from the train station, or wherever they are, because "we knew as soon as they stepped in here we would make a sale" (Founder).

The office wasn't just designed for customers; I also wanted to be sure employees had a comfortable working environment to keep them happy. The software developers and designers (they call themselves Geeks and Creatives) sit at the far end of the office, furthest from the customers. They usually dressed informally and worked how they wanted, but that just gave customers the impression of a young and vibrant company. Sales staff sat just beside the meeting room and they always dressed smartly, so customers could see we are a professional company that deals with serious businesses. We tried to get that balance right to show our ability and our trustworthiness. The sales people have a lot of technical knowledge, but they deliberately play it down when talking to customers, to avoid intimidating them. We made sure that all the documents as well as conversations would be free of any technical jargon. They would always talk customers through everything in a friendly way because we really wanted to build those long term relationships.

What customers could see here was a creative, friendly and productive environment where people want to work. And that's because I took a lot of care to make sure we had the right people and treated them well. "The biggest issue in the company is staff happiness and wellbeing...making money is actually really simple, you just get a bunch of good people and you make money, it's not rocket science... [the biggest challenge is] looking after them" (Founder).

We recruited employees based on how well they would fit in with the team, not just on the basis of their qualifications. When I hire someone, I look at how they communicate in their application, how they conduct themselves in the interview, their musical tastes, and the feel of their handshake. I use my gut feeling as to whether they will fit in and I usually tell them after the interview or as soon as possible afterwards. I prefer to do things this way because customers see all of these qualities, they don't see the employee's CV. On our website, we had information about each team member, including animations of them playing their favorite sports or doing things that characterize them. That really helped to convey their personalities and show our sense of humor. It's really important that these personalities are compatible because I take employee satisfaction really seriously. Sometimes when everyone had been working really hard, I would take them out for dinner to reward them and 
keep them happy. I would usually just shout "stop working, we're going out!" because the office was small enough for everyone to hear. I also made sure we always had snacks in the kitchen and beer in the fridge, and I never saw them abuse that. We had a live video broadcast from our office, so customers could see everyone working hard and looking happy. And the employees were so proud of working here that I even saw one staff member showing their family around the office when I looked at the camera one weekend. I think in ten years we only had one person leaving.

\section{During the Change}

Even though we have had several years of success, ServCo was probably not reaching its potential and needed to grow. Word of mouth was all very well, but we were very restricted to the local market and our social network. And Furthermore, the competition was a lot tougher than when we started in the late 1990s. The next step for us really needed to be getting to know the larger customers that I knew were there, but just out of reach. To get to them, I thought we needed to expand the services we offered. I knew I couldn't do it on my own and needed help to grow the company, even if that meant doing things differently or letting someone else have more control. After a lot of discussion with another local business, I eventually agreed to sell equity in ServCo, to allow me to be less involved and let someone else take over. I thought he could really help the company grow and take us into the new markets that we were always trying to break into.

At the same time, I was starting to be more excited by other projects. We were running a training academy, to help young people get IT skills that would really make a difference in their lives. And I was starting to get more involved in charity work. I had always tried to help local charities, both individually and through ServCo, but to be honest I was starting to find that more rewarding than running the business. During the changes, I spent most of my time coordinating the new office and trying to make that a new home for ServCo. When I handed over control to the MD, I brought him in to the office and introduced him to the team. After that I started to spend more time on charity work.

While we were moving, there was an attempt to define our service concept. This came about as part of employee-led discussions on ServCo's social responsibility. I have always been aware of the company's responsibilities to its customers and to its employees. I never really thought of making money as an aim in life, but having money means you can share it and make people happy. So the idea of social responsibility appealed to me and seemed to be a good foundation on which to build our service concept. And because I trust our employees, I let them take the lead on developing our social responsibility policy. 
After the change

It has been a tough time with all of the disruption and the new people coming in. I thought things would work ok and we would be able to maintain the same great atmosphere we have always had, but I realize now that things aren't quite right. I've focused all of my attention on the new office, but maybe I should have spent more time with people, because I can see the MD didn't quite get how we do things here. I didn't realize there was anything wrong, but then we had an incident with a new appointment. The MD wanted to hire a new office manager, which seemed like a good idea, but the way we have always done things is to look after the people that have been loyal to us. Although there was never a guarantee of promotion, the unwritten rule was to offer opportunities for new positions to existing staff. When I heard that the MD had brought someone new in and had overlooked an internal candidate, I was so upset I came back early from a holiday to apologize to the employee. I won't tell you what was said, but I also had words with the MD about the matter. The problem is I realized people were upset about how things were going and not long after that, we lost one of our longest serving employees who decided to go to another company.

Despite these initial problems around the transition, ServCo is now doing well and it seems that managers and employees have rallied around the service concept that they helped to define: "great services, delivered ethically". However, we need to remain constantly vigilant about employees and their well-being because our services are delivered by these employees and a big part of delivering our services ethically is to treat our employees responsibly.

\section{Narrative Two - New Management (MD’s) Perspective}

\section{Before the change}

I knew ServCo was very successful at keeping its customers and its employees happy. I could see they didn't lose many of either and that must have meant they were well run. I knew the founder had his own way of doing things and employees clearly bought into that - they enjoyed working for the company. What worried me was the very noticeable dependence on a single individual. In such a small company and in a small office where it is possible to shout from one side to other, maybe it works for the founder to be involved in everything and to actively lead employees. In a larger company - which ServCo aspires to become - that didn't seem feasible.

What we needed was more reliance on processes, rather than strong personalities. That is exactly what I see as my role; to get the most out of the potential. The very personal approach was very successful with small customers, but to go after contracts with larger clients, a different approach would be needed. Corporate clients have higher expectations, they want to see demonstrations of capabilities and structure to assure them that the company knows what it's doing, it's not just about trusting individuals. "We did have a flat management structure when we were small...now we are trying to 
put tiers of management in place... we're just trying not to upset how it has been, the right people have been here a long time so we've got to move forward but trying to make sure no-one's nose is out of joint because we are expanding" (MD). To get where we needed to be, we needed clear lines of communication and employees had to be well organized to divide the work and deal with it efficiently. The way things were before, with the informal way of working, employees could be put under intense pressure when there were big projects for demanding clients.

What structure there was seemed to involve the sales people working as a buffer in client-facing roles. They would take all the flak and shield the developers and designers from all the pressures that come with customer contact. What I saw that ServCo needed was to expand this structure, with sales people acting as both account managers and line managers to the back-office employees. I was sure that having these clearly defined roles and reporting lines would help everyone to work better when we started to take on much larger projects, with more pressure.

\section{During the change}

We are a profitable, successful company and my role is to manage everything to make sure we maintain that, including staffing issues and winning new customers.

When I was taking over the day-to-day running of ServCo, my main aim was to improve the processes and structure. From my point of view, all of the work involved in moving to the new office seemed to be a distraction from serious business. Now that we have completed the move, we can mark that task as completed and put all of our focus on improving performance and bringing in new customers.

I can see the results of the office move are excellent and the office is going to make a big impression on customers, but I think "my eyes were taken off of business because of the office" (MD). I think with all of the changes going on, many people had difficulty adjusting. Unfortunately, some people were put under unnecessary pressure because they were asked to take on extra responsibilities during the move. Employees were expected to be very flexible to cope with the extra work, but that really is not sustainable. Instead I think we have to find the right people to fill the roles that are needed to balance everyone's workload. "If there is a new position that is needed, like our new office manager... it's a great benefit to everyone here, but without him we were a bit more fraught" (MD).

When I hire employees, particularly for senior positions, I think the decision should be made carefully to make sure they are well qualified and able to contribute to improving the company. It is important to be thorough and that usually means using recruitment agencies. Even if they can be more expensive, they follow a process that ensures we make the right decisions. Unfortunately, I can see that not everyone appreciates my approach because hiring new people makes the existing employees feel their own positions have been affected. For example, when we appointed the office manager, I 
chose the applicant with the best qualifications. There was an internal candidate, but in my view he didn't have the right skills and experience. When customers come to us, they expect a high standard of service and it is vital we don't disappoint them. The only way we can satisfy our customers is by having the best people with the right skills. Unfortunately, it seems that people expected that the job would be given to the internal candidate and a few people were a bit upset that it wasn't. I think we have always had an open door policy here, but staff may not always recognize it: "I believe that we could do more for the staff during the change, but we are still striving to settle in to the new premises, therefore, it is still a little bit chaotic" (MD). And the problem is, as we get bigger, people get a bit more distant, so I hope they will continue to have good communication but through their line managers.

One thing that helped to address the distance that people felt, was when employees started working to define our social responsibility. This wasn't something I had a big input into, but I can see that it helped everyone to develop a shared concept of the company and what makes it special. At first I thought social responsibility was all about recycling, but I can see that its more about how we treat our employees and how we behave ethically. "The services we provide are ethically oriented and this means that we put our focus on providing professional services that involve happier customers and staff...if employees are happy it will benefit the company" (MD).

\section{After the change}

We always had a reputation for quality and for being a cool place to work. To maintain this, we need to "employ good and talented staff" (MD) and to keep them happy at work. I know "other companies don't look after staff very well" (MD) but we definitely don't fall into that category. We do our best to make people feel welcome so they enjoy coming to work. There are many things the staff here have always done, like going out together or celebrating birthdays in the office. I thought I would welcome one of the new employees by having a birthday celebration. That seemed a nice way to make the new and old staff feel like part of the same team. Things have been stressful but I think they will start to get better soon. "We've put the people in, but they are not quite synched. The whole picture will pick up speed... [after some time] all the cogs, instead of bashing, will all be working together...I can see it happening in the next few months" (MD).

\section{Narrative Three - Employees'Perspective}

\section{Before the change}

For us, working for ServCo has always meant being part of a community with no difference between people in different roles. We have always valued the friendly, informal environment at work and that came directly from the trust and respect we were given by the founder. He valued our technical skills to do our jobs but also treated us as individuals with our own creative abilities. We've always felt able 
to express our creativity because of the environment where in which we worked. The office was nicely designed and fun to work in. Maybe that was because most people were a similar age, had similar interests and even the same taste in music. Like, even if we didn't have the radio on when we were working, sometimes someone would start singing and we would all join in. That's just the way things were and the founder let us get on with it, he even encouraged us to have fun.

We had a very flat management structure and for the Creatives and Geeks at least, there was very little pressure from customers. Those of us doing sales were responsible for explaining options, negotiating contracts and writing specifications. Then we would all work together to deliver on the specs. Having said that, sometimes we knew the customers so well they would phone people directly when they needed something. So in fact the relationship wasn't always customer-supplier, sometimes customers were also part of our community. The great atmosphere was something that everyone could see, even outside. "Customers talk about the workplace and you can appeal to new clients and people through good reputation. It also applies if you are looking for new staff, it can work as a massive benefit" (Old Employee).

\section{During the change}

Even if things were great the way they were, we could understand why the founder felt we needed to grow. Still, when he came in one day and announced that the MD was in charge now, a lot of us felt really confused. We just didn't expect so much to change so suddenly. Most of us had been here for a long time and had earned the trust and respect of the founder and customers. So all of the changes really disrupted that and put us in a bad position. And after being such a close-knit little group, we felt we really needed to keep the culture we have here. "The new people we have brought in need to adapt to the culture here, so it should be talked about more and people should know about it. That's how we probably can keep the culture here alive" (Old Employee). The culture was all of the things that we were used to here, the informal relations with customers, the relaxed work environment and most of all the trust and respect.

Unfortunately, many of the new people are just different. They don't have the same interests or like the same music. And you can see a difference between the two groups - Old and New - even in the seating arrangements. The new employees were all sitting near the MD, they're his people. When he threw a big party for one of the new people, a lot of us were upset. We always had our birthday tradition - a card, a small gift and singing happy birthday, but he didn't really seem to make a fuss, even when one of the old employees had their $40^{\text {th }}$ birthday a few months after we moved into the new office. When one of the new people had their birthday though, the MD definitely made a big fuss. That was way over the top, but I guess it shows who his favorites are.

New employees could see there was something special about working here too, but unlike us, they couldn't see that things were quite quickly changing and we were losing a lot of the culture. "The 
clients seem happy and talk about the great experience they feel when here, so it seems to be working quite well. I mean it all seems to be working, if the strategy is in place to make everyone happy [customers and employees] it seems to be working" (New Employee). For the new employees, it seemed like there is more trust given to employees, compared to other places they worked, where they had pressure and a more hierarchical structure. But for us, it seemed like we were going the wrong way and we were getting more and more formal in everything. We were getting further away from what made ServCo a great place to work.

The new employees were happy to have more processes, like for them it was normal, they thought we were just unhappy because things were changing. "As I have been told the structure in this company was much more open and free of barriers, but I only know this company with these levels of management structure and it is not bothering me. There are always people who don't like changes in every organization, but changes are necessary" (New Employee). For those of us who had been here the longest, all of these formal processes just took all of the enjoyment out of working here. We didn't really see the point and just seemed like the MD was trying to complicate things unnecessarily: "I am not a kind of a process driven person and I like to keep things simple, but my opinion is that if everything is driven by processes... it will lose its power and uniqueness and become bureaucratic. And that is definitely not a company I want to work for and I think that the majority of staff, especially the old staff, agree with me" (Old Employee).

For many of us, it seemed like the MD simply didn't trust us as much as the founder did, he wanted to have more control over everything we do. The problem is that it seems like everything we valued is being pushed out and our way of doing things is under threat. So for us, discussions about ServCo's social responsibility are really important. It was an opportunity to make it clear what our values and our culture are, so we could keep those in place even if the company was growing. "Because we are still in the changes it is difficult to capture the shared understanding. But, actually over time the culture and shared understanding will become consolidated. We have been growing so rapidly...[delivering the service ethically] will guide us in our relation to our customers and internally how we manage our culture here at the office" (Old Employee).

\section{After the change}

The final straw for some people was when the MD wanted to hire a new office manager to look after a lot of the processes that had been put in place. He brought in one of his people rather than hiring one of the old employees who applied for the position. Even though the founder came back to apologize for the mistake, this was an indication of how the respect for us had changed. One of the sales people decided he'd had enough and left not long after. The way he saw it, his role had changed from being equal but customer facing, to suddenly being about managing others. And he felt communication had become too complex with all of the formal processes. This was partly because we were in a bigger 
office on multiple floors to accommodate all the new people, but also because there was talk of an open door policy, but we always had to talk to line managers rather than anyone directly.

For the rest of us, the culture and atmosphere have been damaged, but one good thing is that the founder still spends a lot of time in the office, while working on his charities. He helps to keep a link with customers and remind everyone about the culture and values we have. It seems to us that our customers are still very happy. They like the new office and to them, having the founder around helps to keep the link with the old culture, which is difficult to describe but helps them to have an idea of who we are as a company. How he and the company itself treats its employees and customers has always been really important. That includes not discriminating against anyone who works here. We never really had strict rules "because we all work quite closely together it just becomes a general rule over everyone. Its in our contract not to be naughty but that's it really" (Old employee). It is very important now that we more clearly define what we mean by delivering services ethically. It is something that people do without realizing it, until "you put a label on it and they realize they are doing things related to ethical policies. Every company has its own level of social responsibility whether they call it that or not, it encourages managers to make sure that their staff are happy and to encourage a good work ethic" (Old employee).

\section{Discussion}

Table 1 summarizes and compares the key points from these three narratives. Examining the sequence of events and how they are seen by social actors allows insights to be derived about the actors and their socially constructed cultures (Geertz, 1973). The interpretations, or misinterpretations, reveal more than the events themselves (Gabriel, 2000). Specifically, the narrative approach used to analyze and report the data reveals the multiple identities in the organization and the multiple, misaligned, perspectives on the identity of the organization itself (Brown, 1998; Landau et al., 2014).

\begin{tabular}{llll}
\hline & Before change & During change & After change \\
\hline $\begin{array}{l}\text { Prevailing } \\
\text { service } \\
\text { concept }\end{array}$ & $\begin{array}{l}\text { "We take good care of the } \\
\text { customer" (Founder) }\end{array}$ & $\begin{array}{l}\text { Tension between employees' } \\
\text { ideas of a great place to work } \\
\text { and MD's attempts to impose } \\
\text { structure. } \\
\text { "We are a profitable, } \\
\text { successful company" (MD) }\end{array}$ & $\begin{array}{l}\text { "Great services, delivered } \\
\text { ethically" (shared) }\end{array}$ \\
\hline $\begin{array}{l}\text { Shared/ } \\
\text { Articulated }\end{array}$ & $\begin{array}{l}\text { Unarticulated but shared } \\
\text { because of founder's ideas } \\
\text { and recruitment policy. }\end{array}$ & $\begin{array}{l}\text { Unarticulated and not shared } \\
\text { due to introduction of new } \\
\text { employees and management } \\
\text { approach }\end{array}$ & $\begin{array}{l}\text { Shared service concept } \\
\text { emerging and articulated by } \\
\text { employees through the process } \\
\text { of developing a social } \\
\text { responsibility policy. }\end{array}$ \\
& Founder and sole owner is & $\begin{array}{l}\text { MD taking day-to-day control, } \\
\text { with founder less actively } \\
\text { involved, but coordinating } \\
\text { office move and re-design. }\end{array}$ & $\begin{array}{l}\text { New managing director has } \\
\text { taken over; original founder } \\
\text { spends a lot of time on the new } \\
\text { premises, which helps maintain } \\
\text { the company culture. }\end{array}$ \\
\hline
\end{tabular}




\begin{tabular}{|c|c|c|c|}
\hline & Before change & During change & After change \\
\hline Employees & $\begin{array}{l}\text { Stable number-approximately } \\
12 . \\
\text { Recruitment based on fit with } \\
\text { culture over qualifications. }\end{array}$ & $\begin{array}{l}\text { Rapidly growing number. } \\
\text { Recruitment based on } \\
\text { qualifications and outsourced } \\
\text { to professional agencies. }\end{array}$ & $\begin{array}{l}\text { More stable but greatly } \\
\text { increased-approximately } 40 .\end{array}$ \\
\hline $\begin{array}{l}\text { Work } \\
\text { environment }\end{array}$ & $\begin{array}{l}\text { Autonomous employees. } \\
\text { Divisions in roles (Sales, } \\
\text { Creatives, Geeks), but no } \\
\text { formal hierarchy. } \\
\text { High level of informality, trust } \\
\text { and respect. }\end{array}$ & $\begin{array}{l}\text { Managed employees. Clear } \\
\text { division of roles and authority } \\
\text { (line managers and workers). } \\
\text { Attempts to maintain } \\
\text { autonomy and respect. }\end{array}$ & $\begin{array}{l}\text { Advantages of process } \\
\text { standardizations start to } \\
\text { become apparent; some } \\
\text { attrition among older } \\
\text { employees. }\end{array}$ \\
\hline Customers & $\begin{array}{l}\text { Mostly SMEs or small } \\
\text { government agencies. Highly } \\
\text { personal interactions. Main } \\
\text { source of new customers is } \\
\text { word of mouth. }\end{array}$ & $\begin{array}{l}\text { Targeting larger customers } \\
\text { outside of current social } \\
\text { network. } \\
\text { Most existing customers } \\
\text { retained. }\end{array}$ & $\begin{array}{l}\text { Larger customers added; } \\
\text { customer interaction becomes } \\
\text { more structured; customers } \\
\text { more aware of new service } \\
\text { concept. }\end{array}$ \\
\hline Workplace & $\begin{array}{l}\text { Comfortable and sophisticated; } \\
\text { customers can see developers } \\
\text { at work. }\end{array}$ & $\begin{array}{l}\text { Office space has become too } \\
\text { small }\end{array}$ & $\begin{array}{l}\text { Well-designed new workplace; } \\
\text { greater physical separation } \\
\text { between developers and } \\
\text { customers. }\end{array}$ \\
\hline
\end{tabular}

Table 1 - Summary of changes in ServCo.

Seen from the perspective of the MD, the decisions made appear to be logical and even admirable. His narrative focuses on the need to sustain and grow the business by introducing more structure and efficiency, while retaining the best parts of the company's culture to make sure "no-one's nose is out of joint" (MD). The birthday celebration appears as an attempt to both imitate the behaviour of the founder and to introduce himself and the new employees into the company. Meanwhile the approach to recruitment appears as a logical attempt to hire the best candidate for a job. The responses of employees to both events reveal their fears that their community and its culture are being undermined by new people and new ways of doing things. These events re-enforce their concerns about the MD's attempts to introduce process and structure. Within their narrative, these actions constitute a threat to their identity as professionals. The use of words such as "process" and "cogs" by the MD clash with the beliefs and ideas of employees, who view themselves as individuals, rather than as cogs in a machine. Perhaps the starkest contrast may be the one between the founder's and MD's views on management. Both value and seek to protect their employees, but take very different approaches. Whereas the founder relies on social relations with customers and employees, the MD emphasizes process.

\section{Articulating the service concept}

This work builds upon theory related to PSF management (Løwendahl et al., 2001; von Nordenflycht, 2010) that suggests there is a conflict between managerial control and professional autonomy. This research introduces a nuanced view that suggests this conflict can be reconciled through the process of creating a shared and articulated service concept (Sasser et al., 1978). Løwendahl (2005) argues that 
where multiple professions or educational backgrounds co-exist, the firm "must invest substantial time and effort to develop shared norms and a common code of conduct" (p27).

In the ServCo case, the process of developing social responsibility became the vehicle for those developing it to express what mattered to them. Employees were able to express their dissatisfaction with changes and articulate their expectations of their roles in a non-confrontational manner. As a result, they gave form to the previously tacit service concept. The notion of "great services, delivered ethically" emerged from this process and sums up the service concept. The statement represents the reconciliation of potentially conflicting views of the management and employees. It captures both the MD's view of ServCo as a profitable, successful company and the employees' view of how the company should treat its customers and more importantly its employees. In defining ServCo's social responsibilities, they had identified aspects related to customers, but it was notable that employee wellbeing, autonomy and culture dominated this perception of social responsibility. It appears that the social responsibility process was taken by employees as an opportunity to gain more control. And while this may not have been intended, it helped to serve a very important purpose in reconciling the conflict. The autonomy given to employees in this process allowed them to take ownership, rather than it being simply a consultation exercise. Taking into account the importance of professionals in a PSF, the service concept is likely to emphasise their needs. Given the desire for autonomy that professionals have, control over a process that allows them to surface their beliefs and articulate their needs in a non-confrontational manner helps to overcome potential conflicts. This leads to the following proposition:

P1: An autonomous, employee led process can offer a vehicle for developing a shared and articulated service concept in professional service firms.

\section{PSF challenges and service concept}

The purpose of this research is to understand the tensions during the growth of a PSF and to examine how the development of a shared and articulated service concept could alleviate such tensions. The narratives allow us to compare the misaligned mental pictures on which the tensions are based. Using Maister's (1993) distinctions, the founder adopts an expertise-based approach, whereas the MD relies on a routine-based one. For employees, who view themselves as experts, the autonomy and decision making involvement that come with being valued for expertise are vital parts of the job (Kelley, 1985; Teece, 2003). The MD, like many PSF managers, appears concerned by the inefficiency that these practices entail (Jaakkola, 2011; Lewis and Brown, 2012). Indeed, Starbuck (1992) highlights how the level of decision making autonomy given to professionals in knowledge-intensive firms is difficult to understand for managers and management scholars alike. However, the MD's routine-based approach is misinterpreted by employees as an attempt to restrict them through increased control and what they perceive as unnecessary bureaucracy (Løwendahl, 2005). 
The service concept is shared before the change but, being driven by the founder's ideas, the small size of the company, and the similar backgrounds of employees, does not require articulation. Although the employees believe they have almost complete autonomy, the founder's narrative reveals the extent of his control - even furniture is made to his specifications. He maintains both control and the service concept by recruiting employees who fit his ideas, as demonstrated by his use of social over technical criteria when interviewing. Indeed, most small PSFs have a common culture as a result of staff members sharing social and educational backgrounds (Løwendahl, 2005). Problems arise in ServCo when the shared culture is challenged by the introduction of the MD, with different ideas, and also by new employees who differ in their social, educational and employment backgrounds. While the MD's changes appear well-intentioned, they are seen as threatening by employees until a new balance is achieved. The organizational change literature refers to punctuated equilibrium (e.g. Van de Ven and Poole, 1995) to describe the way that organizations continually move from one settled form to another. ServCo is studied during a change from one equilibrium point to the next and demonstrates how these changes create conflict, but also that the conflicts can be temporary. The narratives reveal that the conflicts arise from different interpretations of the MD's intentions. He views process as a way of shielding individuals from excessive work load; they see process as a threat to their culture. As ServCo settles into a new equilibrium after the change, the clear articulation of the service concept, through the exploration of social responsibility, offers a means to resolve the conflicts by facilitating what Kelley (1985) describes as treaties between management and professionals. This is summarized in Table 2.

\begin{tabular}{llll}
\hline PSF Challenges & Before change & During change & After change \\
\hline Cat herding & $\begin{array}{l}\text { Controlled by maintaining } \\
\text { culture and ensuring } \\
\text { similarity in employee } \\
\text { characteristics. }\end{array}$ & $\begin{array}{l}\text { Problematic due to influx of } \\
\text { new employees and attempts } \\
\text { to introduce processes. }\end{array}$ & $\begin{array}{l}\text { Reduced by articulating a } \\
\text { service concept built around } \\
\text { the idea of social } \\
\text { responsibility. }\end{array}$ \\
\hline Opaque quality & $\begin{array}{l}\text { Addressed by managing } \\
\text { impressions through social } \\
\text { interactions and interior } \\
\text { design. }\end{array}$ & $\begin{array}{l}\text { Attempts to maintain } \\
\text { reputation and use formal } \\
\text { processes to convey quality. }\end{array}$ & $\begin{array}{l}\text { Conveyed to customers } \\
\text { through commitment to } \\
\text { social responsibility } \\
\text { embedded in an articulated } \\
\text { service concept. }\end{array}$ \\
\hline $\begin{array}{l}\text { Lack of process } \\
\text { standardization }\end{array}$ & $\begin{array}{l}\text { Not addressed, restricting } \\
\text { further growth. }\end{array}$ & $\begin{array}{l}\text { Being addressed through } \\
\text { development of formal } \\
\text { processes and management } \\
\text { structure. }\end{array}$ & $\begin{array}{l}\text { Processes in place to } \\
\text { maintain standards and } \\
\text { manage workload, which } \\
\text { resonates with the socially } \\
\text { responsible service concept. }\end{array}$ \\
\hline
\end{tabular}

Table 2 - PSF challenges as observed in ServCo.

The narratives reveal that without the service concept, misalignment of mental images is the root of conflicts. This leads to the second proposition: 
P2: Developing a shared and articulated service concept helps to overcome the challenges of professional service firms during organizational change by revealing conflicts between the mental images of management, employees and customers.

The cat herding challenge was not problematic before the change because of the freedom, trust and other non-monetary rewards in evidence (Goodale et al., 2008). Essentially, people did not treat their work as just a job, but like most professionals, enjoyed the company and stimulation of working with like-minded professionals. While the new MD appreciated that that people enjoyed their jobs and understood why, he saw his role as ensuring profitability and success. He also felt the best way to create a positive work environment was to manage capacity by limiting the workload of people in key positions who may otherwise have become overwhelmed. Problems arose because of his failure to communicate the intentions of the management structure he introduced. It was misinterpreted by employees as a restricting their freedom, reducing their responsible autonomy (Friedman, 1977) and therefore treating them less as responsible professionals and more like resources.

These restrictions on freedom are problematic because professionals "even more than the overall work force... want access to relevant information, consultation and true (rather than token) participation in management decision making” (Kelley, 1985, p13). A notable feature of the company's new social responsibility policy was the emphasis on employee related aspects such as work-life balance and flat management structure. Although they also identified environment related aspects, employees focused on what they feel management owed them - freedom, respect and trust. In other types of service firms, the service concept may emphasize the duties and responsibilities of employees towards managers and especially customers. With professional workers involved, however, the focus is more on the responsibilities of employees towards customers and the rights they demand of their managers. This leads to the third proposition:

P3: A shared and articulated service concept can alleviate the cat herding challenge in professional service firms because it aligns managers' and employees' mental pictures of their rights and responsibilities.

The opaque quality challenge in ServCo is typically overcome through a strong emphasis on visual and aesthetic design. Design in the workplace is important because it influences both employees' and employees' perceptions (Lorenz, 1987, West and Wind, 2007). And in PSFs it can be particularly important because the workplace is shared by employees and customers in their close interactions. In the absence of information, clues about service quality come from appearances - a surgeon's untied shoelace may imply a poor quality for example (Berry et al., 2003). Appearances are controlled when managers select ServCo's company cars and artwork to reflect the service concept they seek to convey to customers. 
Aesthetic matters also have important symbolic value for employees. Sales staff (seated close to the customer meeting room) dress smartly whereas others (seated further away) dress more comfortably. And employees were previously selected for their ability to fit in, for example considering their musical taste, reflected in the spontaneous singing. Aesthetic matters such as clothing and musical tastes are considered important signifiers of belonging to certain social groups and identifying with others in those groups (Bourdieu, 1979). For example, in Rosen's (1985) study of an annual event held by an advertising agency for its employees, dressing in suits signified employees seeking promotion or approval from superiors, while dressing differently marked someone out as belonging to a creative subculture. Rosen suggests that awards for long service re-enforce employees' views that conformity, not creativity was demanded of them, because they took place alongside senior executives' speeches criticising some employees' poor attitudes.

The profile of ServCo's employees has changed, but after the changes a new culture and patterns of social interaction have developed. This is evident from the way employees are portrayed on the company's website. Whereas, before the change, individuals and their interests were displayed, postchange there is more emphasis on group activities. Weddings, births and sponsored marathons are reported, along with trips made by the whole ServCo team. These activities demonstrate the work-life balance that employees seek, but also present the employees as a team and community to customers. Løwendahl's (2005) stage C PSF (see Figure 1) has a focus on creative problem solving and teambased knowledge and these can be seen from the information revealed to customers on the website. Design of the website, along with interior design, was previously aligned with the founder's ideas. As the service concept has been articulated by employees, the website and workplace design have come to represent the shared culture that has emerged from the old and new. And these offer vital clues to customers as to the service quality and experience they can expect to receive. This leads to the fourth proposition:

P4: A shared and articulated service concept can alleviate the opaque quality challenge in professional service firms because it aligns customers' and employees' mental pictures of service process and outcomes.

A lack of process standardization can be seen as a challenge for managers, who regularly seek to use process control as a means to improve efficiency as well as effectiveness of PSFs (Jaakkola, 2011). Employees, on the other hand, are less likely to be concerned because, as the narratives suggest, they view process standardization as a restriction to their freedom. They appreciate the problem solving inherent in treating every task as a unique project, rather than a repetition of a standard solution. For the organization this creates inefficiency which may be treated as simply a cost of business. However, as Lewis and Brown (2012) argue, the inefficiency soon has an adverse effect on customer perceptions, since customers expect prices to fall in difficult economic times, whereas in industries 
such as legal practice, they have continued to rise. The MD's approach to tackle inefficiency included time recording and prescribed processes that were seen to "get in the way of working" (old employee), matching Lewis and Brown's (2012) observation that professionals follow such processes reluctantly because they view them as separate from more enjoyable and important work matters.

Rather than seeing the introduction of process standardization as a threat, however, ServCo employees could consider the MD's stated intentions, which are to reduce and balance the workload pressure on particular employees that he views as unsustainable if the company is to fulfill its potential. Standardizing solutions to simple problems can be seen as turning simple tasks into Maister's (1993) grey hair problems, meaning less time is spent on the things that have been done previously and more time devoted to new problem solving challenges that demand creativity. Expressed in this manner, the changes would be well aligned with the service concept, but without clear communication of intent the narratives demonstrate there is conflict. Hence, the fifth proposition:

P5: A shared and articulated service concept can alleviate the process standardization challenge in professional service firms because it allows processes to be introduced without threatening the roles of employees.

\section{Managerial Implications}

With the increasingly knowledge based and service driven nature of many industries, managing professional knowledge workers is becoming relevant beyond the context of traditional PSFs (Teece, 2003). The paradox of managing professionals is that managerial control over the means of production - the professional workforce - risks negatively impacting its efficiency. Acceptance of this fact can lead managers to take a very personal approach such as ServCo's founder, granting considerable rights and freedoms to the professionals. This works because employees treat him more like a friend than an employer and are motivated by the desire to not let him down. However, as Løwendahl (2005) demonstrates, the typical evolution of a PSF sees its management try to impose control, due to concerns about efficiency (Lewis and Brown, 2012). The result can have unexpectedly negative consequences (such as when one of ServCo's original senior employees decided to leave). Such occurrences appear to be commonplace in the growth and development of a PSF and call for nuanced managerial strategies to deal with them. The narrative methodology used in this study helps to diagnose the cause of discontent among the employees as a PSF grows and seeks to introduce more routine based ways of working (Maister, 1993). A misalignment in the mental pictures of the service leads to misunderstandings of the purpose of organizational change and leads to perceived threats to employees' culture and practice. However, as ServCo demonstrates, the challenges can be overcome when mental pictures are aligned. In this case, the vehicle of the development of the social responsibilities of the company towards its employees and customers had the effect of allowing a nonconfrontational articulation of the service concept by the employees. Importantly, the employees were 
given control over this vehicle by management. The outcome of the social responsibility process was an articulation of the employees' defined service concept, which helped to clarify what they value and make the culture more visible. The MD adapted to the employee defined service concept and made efforts to reconcile the differences between his preferred methods and those of the employees. Due to the balance of power in PSFs, the shared concept was led by employees, which may not be the case in other types of services. However, the process of articulating the concept, which happened as a byproduct of the social responsibility development, was valuable in reconciling the tensions between management and new/old employees. Therefore, developing a shared and articulated service concept can guide managers in communicating their decisions, designing organizations and working practices in a way that accounts for professional workers' needs. It also acts as a guide for design of all customer-facing aspects of the service, to ensure consistency of purpose and to communicate the quality of the service to customers. As a result, the main recommendation of this study for managers of PSFs is to engage with employees in jointly developing a shared and articulated service concept, to help overcome the challenges of cat herding, opaque quality and process standardization, particularly during organizational change. In the case of ServCo a non-confrontational process was (opportunistically) used to articulate and surface differing interpretations of the service concept and combined with management adaptation resulted in a new and shared service concept. Hence, to overcome the tensions between managerial control and professional employee autonomy nonconfrontational vehicles should be used; such as, the development of strategy, codes of professional conduct, mission statements or explicitly to develop a service concept itself.

\section{Limitations}

While multiple case study methods seek triangulation, in other words using multiple sources to find a true representation, this single case study deliberately seeks multiple representations and misrepresentations of events. As Van de Ven and Poole (1995) argue, a way of seeing is also a way of not seeing, meaning seeking triangulation to find one consistent view risks obscuring others that may be equally important. This may be seen as subjective, since the authors' interpretations of informants' subjective views are presented. However, the value of the narrative approach lies in its ability to see events from multiple perspectives. Care was taken to ensure the fairness and trustworthiness of the narratives, in other words ensuring that the interpretations were acceptable to the informants and can be trusted by readers. Additionally, the authenticity, plausibility and criticality of the narratives were emphasized in order to convince readers (Golden-Biddle and Locke, 1993).

An unavoidable limitation of longitudinal studies is that the story never truly ends. While the narratives are presented with a beginning, middle and end, it is clear that change is ongoing. This is not the end of the story, merely one equilibrium point in the evolution of this organization. 


\section{Conclusion}

Managers of PSFs face three distinctive challenges that make their work difficult. These are managing autonomous employees (referred to as cat herding), difficulty in communicating the process and outcome (opaque quality) and the lack of process standardization. While managers naturally seek ways to standardize and improve processes, employee resistance to such changes can have harmful effects. The service concept, which is proposed to offer a missing link between management, employees and customers (Goldstein et al., 2002) offers a potential solution. This paper contributes to the literature on the service concept by conceptualizing the challenges of PSFs as resulting from the lack of a shared and articulated service concept. It also contributes to the literature on PSFs by using a narrative methodology to uncover misalignment of mental pictures and how a shared and articulated service concept could align them. And finally, it offers research propositions and managerial implications related to PSF challenges and the service concept.

\section{References}

Abbott, A. (1992), "From causes to events: Notes on narrative positivism", Sociological Methods and Research, Vol. 20, No. 4, pp. 428-455.

Berry, L.L. and Bendapudi, N. (2003), "Clueing in customers", Harvard Business Review, Vol.81, No.2, pp.100-106.

Berry, L.L., Parker, D., Coile, R.C., Hamilton, D.K., O’Neill., D.D. and Sadler, B.L., (2004), “The business case for better buildings", Frontiers of Health Services Management, Vol. 21, No. 1, pp. 324.

Bourdieu, P. (1984), Distinction: A social critique of the judgment of taste, Harvard University Press, Boston, MA.

Brown, A.D. (1998), "Narrative, politics and legitimacy in an IT implementation", Journal of Management Studies, Vol. 35, No. 1, pp.35-58.

Chambers, E. (2003), “Applied Ethnography”, In: Denzin, N.K. and Lincoln, Y.S. Collecting and interpreting qualitative materials, $2^{\text {nd }}$ ed. p389-419, Thousand Oaks, CA: Sage.

Clark, G., Johnston, R. and Shulver, M. (2000), "Exploiting the service concept for service design and development”, In: Fitzsimmons, J.A. and Fitzsimmons, M.J. (Eds.) (2000) New service development: creating memorable experiences, Sage, London.

Dubois, A. and Gadde, L.E. (2002), "Systematic combining: an abductive approach to case research", Journal of Business Research, Vol. 55, No. 7, pp. 553-560. 
Dubois, A. and Gadde, L.E. (2014), "Systematic combining-A decade later", Journal of Business Research, Vol. 67, No. 6, pp.1277-1284.

Dyer, W.G. and Wilkins, A.L. (1991), "Better stories, not better constructs, to generate better theory: A rejoinder to Eisenhardt", Academy of Management Review, Vol. 16, No. 3, pp. 613-619.

Eisenhardt, K.M. (1989), "Building theories from case study research", Academy of Management Review, Vol. 14, No. 4, pp. 532-550.

Friedman, A. (1977), Industry and Labour, MacMillan, London.

Gabriel, Y. (2000), Storytelling in organizations: facts, fictions, and fantasies, Oxford University Press, Oxford.

Geertz, C. (1973), Interpretation of Cultures, Basic Books, New York, NY.

Gilbert, C.G. (2005), "Unbundling the structure of inertia: resource versus routine rigidity", Academy of Management Journal, Vol. 48 No. 5, pp. 741-763.

Golden-Biddle, K. and Locke, K. (1993), “Appealing work: an investigation of how ethnographic texts convince", Organization Science, Vol. 4 No. 4, pp. 595-616.

Goldstein, S.M., Johnston, R., Duffy, J. and Rao, J. (2002), “The service concept: the missing link in service design research?", Journal of Operations Management, Vol. 20, No. 2, pp. 121-134.

Goodale, J.C., Kuratko, D.F. and Hornsby, J.S. (2008), "Influence factors for operational control and compensation in professional service firms", Journal of Operations Management, Vol. 26, No. 5, pp. $669-688$.

Guba, E.G. and Lincoln, Y.S. (2005), "Paradigmatic controversies, contradictions and emerging confluences", in Denzin, N. and Lincoln, Y.S. (Eds) The Sage Handbook of Qualitative Research, pp. 191-215, Thousand Oaks, CA: Sage.

Hakanen, T. and Jaakkola, E. (2012), "Co-creating customer-focused solutions within business networks: a service perspective", Journal of Service Management, Vol. 23, No. 4, pp. 593-611.

Harvey, J. (1998), "Service quality: a tutorial", Journal of Operations Management, Vol. 16, No. 5, pp. 583-597.

Jaakkola, E., (2011), "Unraveling the practices of "productization" in professional service firms", Scandinavian Journal of Management, Vol. 27 No. 2, pp. 221-230.

Johnston, R., Clark, G. and Shulver, M. (2011), Service operations management, improving service delivery, 4th edition, Pearson, Harlow. 
Kelley, R.E. (1985), The gold-collar worker: harnessing the brainpower of the new work force, Addison-Wesley, Reading, MA.

Kellogg, D.L. and Nie, W. (1995), “A framework for strategic service management”, Journal of Operations Management, Vol. 13, No. 4, pp.323-337.

Landau, D., Drori, I. and Terjesen, S. (2014), "Multiple legitimacy narratives and planned organizational change", Human Relations, Vol. 67, No. 11, pp. 1321-1345.

Langley, A., Smallman, C., Tsoukas, H. and Van de Ven, A.H. (2013), "Process studies of change in organization and management: unveiling temporality, activity and flow", Academy of Management Journal, Vol. 56, No. 1, pp. 1-13.

Levitt, T. (1981), "Marketing intangible products and product intangibles", Harvard Business Review, Vol.59, No.3, pp.94-102.

Lewis, M.A. and Brown A.D. (2012), "How different is professional service operations management?", Journal of Operations Management, Vol. 30, No. 1, pp. 1-11.

Lorenz, C. (1986), The Design Dimension: The New Competitive Weapon for Businesses, New York: Blackwell.

Løwendahl, B.R., Revang, Ø. and Fosstenløkken, S.M. (2001), "Knowledge and value creation in professional service firms: A framework for analysis", Human Relations, Vol. 54 No. 7, pp. 911-931.

Løwendahl, B.R. (2005), Strategic Management of Professional Service Firms, $2^{\text {nd }}$ ed., Copenhagen Business School Press, Copenhagen, Denmark.

Maister, D. (1993), Managing the professional service firm, Free Press, New York, NY.

Narayanan, V.K., Colwell, K. and Douglas, F.K. (2009), "Building organizational and scientific platforms in the pharmaceutical industry: a process perspective on the development of dynamic capabilities", British Journal of Management, Vol. 20, No. S1, pp. S25-S40.

Nonaka, I. and Takeuchi, H. (1995), The knowledge-creating company: How Japanese companies create the dynamics of innovation, Oxford University Press, Oxford.

Norman, D. (1990), The design of everyday things, New York, NY: Basic Books.

Pentland, B.T. (1999), "Building process theory with narrative: from description to explanation", Academy of Management Review, Vol. 24, No. 4, pp. 711-724.

Raelin, J.A. (1986), The clash of cultures: managers and professionals, Harvard Business School Press, Boston, MA. 
Rosen, M. (1985), "Breakfast at Spiros: Dramaturgy and dominance", Journal of Management, Vol. 11, No. 1, pp. 31-48.

Roth, A.V. and Menor, L.J. (2003), "Insights into Service Operations Management: A Research Agenda", Production and Operations Management, Vol. 12, No. 2, pp. 145-163.

Schmenner, R. (1986), "How can service businesses survive and prosper?", Sloan Management Review, Vol. 23, No. 7, pp. 21-32.

Sieg, J.H., Fischer, A., Wallin, M.W. and von Krogh, G. (2012), "Proactive diagnosis: how professional service firms sustain client dialogue", Journal of Service Management, Vol. 23, No. 2, pp. 253-278.

Simons, R. (2000), Performance measurement and control systems for implementing strategy, Prentice Hall, Upper Saddle River, NJ.

Starbuck, W. (1992), "Learning by knowledge-intensive firms", Journal of Management Studies, Vol. 29, No. 6, pp. 713-740.

Sweeney, J.C., Geoffrey N.S. and McColl-Kennedy, J.R.. (2011), "The marketing practicesperformance relationship in professional service firms", Journal of service management, Vol. 22, No. 3, pp. 292-316.

Teece, D.J. (2003), "Expert talent and the design of (professional services) firms", Industrial and Corporate Change, Vol. 12 No. 4, pp. 895-916.

Van de Ven, A.H. and Poole, M.S. (1995), "Explaining development and change in organizations", Academy of Management Review, Vol. 20 No. 3, pp. 510-540.

Von Nordenflycht, A. (2010), "What is a professional service firm? Toward a theory and taxonomy of knowledge-intensive firms", Academy of Management Review, Vol. 35, No. 1, pp. 155-174.

Wemmerlöv, U. (1990), “A taxonomy for service processes and its implications for system design”, International Journal of Service Industries Management, Vol. 1, No. 3, pp. 20-40.

West, A.P. and Wind, Y. (2007), "Putting the organization on wheels: workplace design at SEI", California Management Review, Vol.49, No. 2, pp.138-153. 